\title{
Characterization of fresh and aged organic aerosol emissions from meat charbroiling
}

\author{
Christos Kaltsonoudis ${ }^{1,2}$, Evangelia Kostenidou ${ }^{1}$, Evangelos Louvaris ${ }^{1,2}$, Magda Psichoudaki ${ }^{1,2}$, \\ Epameinondas Tsiligiannis $^{1,2}$, Kalliopi Florou ${ }^{1,2}$, Aikaterini Liangou ${ }^{1,2}$, and Spyros N. Pandis ${ }^{1,2,3}$ \\ ${ }^{1}$ Institute of Chemical Engineering Sciences, ICE-HT, Patras, Greece \\ ${ }^{2}$ Department of Chemical Engineering, University of Patras, Patras, Greece \\ ${ }^{3}$ Department of Chemical Engineering, Carnegie Mellon University, Pittsburgh, USA
}

Correspondence to: Spyros N. Pandis (spyros@ andrew.cmu.edu)

Received: 4 November 2016 - Discussion started: 21 November 2016

Revised: 14 April 2017 - Accepted: 24 April 2017 - Published: 15 June 2017

\begin{abstract}
Cooking emissions can be a significant source of fine particulate matter in urban areas. In this study the aerosol- and gas-phase emissions from meat charbroiling were characterized. Greek souvlakia with pork were cooked using a commercial charbroiler and a fraction of the emissions were introduced into a smog chamber where after a characterization phase they were exposed to UV illumination and oxidants. The particulate and gas phases were characterized by a high-resolution time-of-flight aerosol mass spectrometer (HR-ToF-AMS) and a proton-transfer-reaction mass spectrometer (PTR-MS) correspondingly. More than $99 \%$ of the aerosol emitted was composed of organic compounds, while black carbon (BC) contributed $0.3 \%$ and the inorganic species less than $0.5 \%$ of the total aerosol mass. The initial $\mathrm{O}: \mathrm{C}$ ratio was approximately 0.09 and increased up to 0.30 after a few hours of chemical aging (exposures of $10^{10}$ molecules $\mathrm{cm}^{-3} \mathrm{~s}$ for $\mathrm{OH}$ and $100 \mathrm{ppbh}$ for ozone). The initial and aged AMS spectra differed considerably $\left(\theta=27^{\circ}\right)$. Ambient measurements were also conducted during Fat Thursday in Patras, Greece, when traditionally meat is charbroiled everywhere in the city. Positive matrix factorization (PMF) revealed that cooking organic aerosol (COA) reached up to $85 \%$ of the total OA from 10:00 to 12:00 LST that day. The ambient COA factor in two major Greek cities had a mass spectrum during spring and summer similar to the aged meat charbroiling emissions. In contrast, the ambient COA factor during winter resembled strongly the fresh laboratory meat charbroiling emissions.
\end{abstract}

\section{Introduction}

Organic aerosol (OA) is one of the main components of atmospheric particulate matter (PM) (Kanakidou et al., 2005; Zhang et al., 2007). Identification of the sources of OA has proven to be a difficult task due to their diversity and the continuous chemical evolution of the corresponding organic compounds. The aerosol mass spectrometer (AMS, Aerodyne Research) provides continuous information (OA mass spectra) that allows the identification of some OA sources. Additionally, the $\mathrm{OA}$ elemental ratios $(\mathrm{O}: \mathrm{C}, \mathrm{H}: \mathrm{C}, \mathrm{N}: \mathrm{C})$ can be calculated providing useful information about the average chemical state of the OA (Aiken et al., 2008). Positive matrix factorization (PMF) (Paatero and Tapper, 1994; Lanz et al., 2007) is often used to deconvolute the AMS data into a linear combination of factors. The resulting OA factors are associated with primary OA (POA), such as the hydrocarbonlike organic aerosol (HOA) or oxidized OA (OOA), which in many cases is related to secondary OA (SOA) (Zhang et al., 2007). Factors linked to biomass burning emissions (BBOA), cooking organic aerosol (COA), and marine emissions (MOA) have also been identified. The OOA has been further separated into factors based on their degree of oxidation and volatility (Zhang et al., 2007; Kostenidou et al., 2009, 2015; Sun et al., 2011; Ge et al., 2012; Mohr et al., 2012; Crippa et al., 2013a, b).

COA has been found to represent $10-35 \%$ of the total OA measured in urban locations (Allan et al., 2010; Sun et al., 2011, 2012; Ge et al., 2012; Mohr et al., 2012; Crippa et al., 2013a, b; Lee et al., 2015). In Greece the COA levels 
have been estimated in two major cities: Athens and Patras. During the summer the COA-related source (named HOA2) was 17 and $14 \%$ of the total OA in Athens and Patras, respectively (Kostenidou et al., 2015). For the winter the corresponding contributions were $16 \%$ for Athens and $12 \%$ for Patras (Florou et al., 2017).

Emissions from meat cooking may produce large amounts of aerosol up to $40 \mathrm{~g} \mathrm{~kg}^{-1}$ (Hildemann et al., 1991). The types of meat cooked (chicken, beef, etc.), other food ingredients, and the cooking method affect both the aerosol emission rate and the composition of the corresponding particles (Rogge et al., 1991; Mohr et al., 2009; He et al., 2010). For example, Allan et al. (2010) suggested that the oil used during meat frying may contribute more to the emitted PM than the meat itself in urban areas in the United Kingdom.

Meat cooking particles contain palmitic acid, stearic acid, oleic acid, nonanal, 2-octadecanal, 2-octadecanol, and cholesterol (Rogge et al., 1991). Schauer et al. (2002) measured the emissions from cooking with seed oils, showing that this process is a source of n-alkanoic and n-alkenoic acids. Allan et al. (2010) reported AMS spectra for several oils used for cooking, showing similar spectra (with enhanced fractions of signal at $m / z, 41$ and 55) with some COA factors reported in the literature.

Most of the AMS spectra from ambient measurements related to COA are characterized by peaks at $m / z$ values 41 , $43,55,57,69$, etc. and have an $\mathrm{O}: \mathrm{C}$ ratio ranging from 0.08 to 0.21 (Mohr et al., 2009, 2012; Allan et al., 2010; He et al., 2010; Sun et al., 2011, 2012; Ge et al., 2012; Crippa et al., 2013a, b; Hayes et al., 2013). He at al. (2010) reported coefficients of determination $\left(R^{2}\right)$ of $0.95-0.98$ among the spectra of OA emissions from different types of Chinese cooking despite the differences in ingredients and cooking methods. Mohr et al. (2009) compared the spectra of OA produced by grilling of hamburgers and chicken without skin. $R^{2}$ values greater than 0.9 were found between these AMS spectra. Mobile aerosol measurements indicate that commercial and residential cooking contribute to enhanced OA concentrations (Elser et al., 2016).

Despite the previous efforts, there are a number of remaining questions regarding the characterization of the emissions related to cooking practices. Separation of COA from the HOA and other primary components is still a challenge for the PMF analysis (Mohr et al., 2009; Kostenidou et al., 2015). Ots et al. (2016) attempted to constrain COA emissions in the UK using the AMS-PMF results. Furthermore, the fate of these primary emissions in the atmosphere is still unknown. The reactions with ozone $\left(\mathrm{O}_{3}\right)$ and $\mathrm{OH}$ radicals may significantly alter these aerosols. Hearn et al. (2005) studied the reaction of oleic acid particles with ozone and concluded that relatively fast heterogeneous reactions occur at the surface of the particles. Dall'Osto et al. (2015) reported different COA factors for a rural site in the Po Valley, Italy, with one being associated partially with primary organic aerosol components such as HOA and partially with sec- ondary components. In contrast, the second COA factor did not correlate with primary tracers. Kostenidou et al. (2015) reported an HOA-2 factor for the summer measurements in Athens and Patras, Greece, that appeared to be associated with cooking but was quite different from the COA factor identified in winter in the same areas by Florou et al. (2017). The reasons for the differences of the COA factor spectra even when the cooking practices are the same in the two seasons were not clear. Due to the mild climate in Greece, there is no significant change in what is cooked during the different seasons as opposed for example to cities in much colder climates.

The aim of this work is to characterize the particulate emissions of pork charbroiling, an activity that is thought to produce large amounts of OA. Smog chamber experiments were conducted in order to characterize the fresh and aged meat charbroiling emissions. The resulting spectra were compared to COA factors derived from ambient measurements in Greece during different periods of the year in an effort to explain the apparent differences in COA spectra derived from the PMF analysis.

\section{Experimental procedures}

\subsection{Chamber experiments}

A set of five smog chamber experiments were conducted in the ICE-HT environmental chamber facility. This facility is composed of a temperature-controlled smog chamber room $(3 \mathrm{~m} \mathrm{~W} \times 4.5 \mathrm{~mL} \times 2.5 \mathrm{~m} \mathrm{H})$ incorporating over $300 \mathrm{UV}$ light lamps (Osram, L36W/73) capable of producing a $J_{\mathrm{NO}_{2}}$ of $0.6 \mathrm{~min}^{-1}$ (when all lights are turned on). The reactor had a volume of $10 \mathrm{~m}^{3}$. A commercial charbroiler was used for the meat cooking. Natural wood coal was purchased from local distributors. A butane burner was used for the ignition of the coal. The charbroiler was placed outside the laboratory and adequate time was allowed for the coal ignition. Pork was purchased from the local market. The meat was cut into $2 \times 2 \times 1 \mathrm{~cm}$ pieces which were placed on wood sticks (length: $20 \mathrm{~cm}$ ). Approximately $100 \mathrm{~g}$ of meat were used for each souvlaki. This type of cooking is widely used in Greece, both in restaurants and homes. Ten to 15 souvlakia were cooked for approximately $20 \mathrm{~min}$. Using a metal bellows pump (Senior Aerospace, model MB 602) a fraction of the emissions was introduced into the $10 \mathrm{~m}^{3}$ Teflon (PTFE) chamber that had been pre-filled with clean air. Insulated $0.375 \mathrm{in}$. copper tubing (less than $2.5 \mathrm{~m}$ in length) was used to transfer the cooking emissions into the chamber. The copper tubing used for the sampling was insulated and was therefore heated by the exhaust vapors. We have confirmed that the metal bellows pump, as expected based on its design, does not generate particles or volatile organic compounds (VOCs). The $\mathrm{PM}_{1}$ losses in this pump have been characterized previously (Kostenidou et al., 2013) using two scanning mobility par- 
Table 1. Summary of smog chamber experiments.

\begin{tabular}{lllrrrrrrr}
\hline $\begin{array}{l}\text { Chamber } \\
\text { exp. }{ }^{1}\end{array}$ & $\begin{array}{l}\text { Initial } \mathrm{PM}_{1} \\
\text { concentration } \\
\left(\mu \mathrm{g} \mathrm{m}^{-3}\right)\end{array}$ & $\begin{array}{l}\text { Aging } \\
\text { procedure }\end{array}$ & $\begin{array}{r}\text { Initial } \\
\mathrm{O}: \mathrm{C}\end{array}$ & $\begin{array}{r}\text { Initial } \\
\mathrm{H}: \mathrm{C}\end{array}$ & $\begin{array}{r}\text { Final } \\
\mathrm{O}: \mathrm{C}\end{array}$ & $\begin{array}{r}\text { Final } \\
\mathrm{H}: \mathrm{C}\end{array}$ & $\begin{array}{r}\text { Average } \\
\mathrm{OH} \\
\left(\mathrm{molec} \mathrm{cm}^{-3}\right)\end{array}$ & $\begin{array}{r}\mathrm{O}_{3} \\
\text { formed } \\
(\mathrm{ppb})\end{array}$ & $\begin{array}{r}\theta \text { angle } \\
\text { initial vs. } \\
\text { final }\end{array}$ \\
\hline 1 & 130 & UV illumination $(4 \mathrm{~h})$ & 0.11 & 1.91 & 0.27 & 1.80 & $-{ }^{2}$ & 35 & 22 \\
2 & 400 & UV illumination $(8 \mathrm{~h})$ & 0.10 & 1.91 & 0.30 & 1.76 & $2.6 \times 10^{6}$ & 47 & 27 \\
3 & 450 & $\mathrm{O}_{3}$ addition $(42 \mathrm{ppb})$ & 0.10 & 1.95 & 0.21 & 1.90 & $6.5 \times 10^{4}$ & - & 16 \\
4 & 335 & UV illumination $(7.5 \mathrm{~h})$ & 0.10 & 1.97 & 0.27 & 1.85 & $1.4 \times 10^{6}$ & 38 & 25 \\
5 & 540 & None & 0.09 & 1.97 & 0.09 & 2.00 & $6.4 \times 10^{5}$ & 0 & 2.6 \\
\hline
\end{tabular}

${ }^{1}$ The total duration of experiments $1-4$ was $7-8 \mathrm{~h}$ and that of Experiment 5 was $4.5 \mathrm{~h}$.

${ }^{2}$ In Experiment 1 no d-butanol was added, and thus no $\mathrm{OH}$ radical concentration is reported.

ticle sizer (SMPS) systems for both ammonium sulfate and ambient particles. The losses were less than $10 \%$ for particles larger than $150 \mathrm{~nm}$, increasing to $30 \%$ for $100 \mathrm{~nm}$ particles. The flow rate for the transfer line was approximately $170 \mathrm{~L} \mathrm{~min}^{-1}$. The temperature and relative humidity were in the range of $20-25^{\circ} \mathrm{C}$ and $15-35 \%$, respectively. Air was sampled $1 \mathrm{~m}$ above the charbroiler for approximately $10 \mathrm{~min}$ in order to achieve a concentration inside the chamber of the order of $100-500 \mathrm{\mu g} \mathrm{m}^{-3}$. The conditions of each experiment are shown in Table 1 . The $\mathrm{NO}_{x}$ concentrations were in the range from 1.5 to $8 \mathrm{ppb}$. The $\mathrm{NO}_{2}$-to-NO ratio ranged from 2 to above 10 . The $\mathrm{NO}_{x}$ analyzer used is sensitive to other $\mathrm{NO}_{y}$ compounds and thus its measurements represent an upper limit of $\mathrm{NO}_{2}$.

A high-resolution time-of-flight aerosol mass spectrometer (HR-ToF-AMS, Aerodyne Research Inc.) measured the non-refractory $\mathrm{PM}_{1}$ aerosol. The vaporizer temperature was set at $600^{\circ} \mathrm{C}$ and the voltage difference between the filament and the ion chamber was $70 \mathrm{~V}$. The $\mathrm{V}$ mode of the AMS was used in these experiments. A SMPS (classifier model 3080, DMA model 3081, CPC model 3787, TSI) measured the particulate number size distribution. The sheath flow rate was $5 \mathrm{~L} \mathrm{~min}^{-1}$ and the sample flow rate was $1 \mathrm{~L} \mathrm{~min}^{-1}$. The size range of the SMPS under this configuration is from 10 to $500 \mathrm{~nm}$. The $10: 1$ ratio provides more accurate size distribution measurements as the instrument has a sharper transfer function but it reduces the measurement range to $10-300 \mathrm{~nm}$. Given the modest size accuracy requirements in this study (a few percent), we selected to cover a larger size range instead. A multiple-angle absorption photometer (MAAP, Thermo Scientific Inc.) was used for the measurement of the $\mathrm{PM}_{1}$ particulate black carbon (BC).

Quartz filters, placed after a $\mathrm{PM}_{2.5}$ cyclone, were used to collect samples of the emitted COA from directly above the charbroiler and from inside the chamber at the end of selected experiments. These samples were used for the measurement of the organic (OC) and elemental carbon (EC) by thermal - optical analysis (Sunset Laboratory Inc., EUSAAR 2 protocol) and for the analysis of the water-soluble organic carbon (WSOC). For the WSOC extraction a $P$ parameter value equal to $0.1 \mathrm{~cm}^{3} \mathrm{~m}^{-3}$ was used according to Psichoudaki and Pandis (2013). The $P$ parameter expresses the ratio of the water used for the extraction of WSOC per volume of air sampled on the filter to be analyzed. Samples were collected on Teflon (PTFE) filters in one experiment in order to estimate the particulate mass emission factor from the charbroiling of pork. Air was sampled from the charbroiler (just above the pork) at a rate of $225 \mathrm{~L} \mathrm{~min}^{-1}$ through a custombuilt exhaust line $(100 \mathrm{~mm}$ id). A portion of these emissions were sampled through a $0.375 \mathrm{in}$. line after passing through a $\mathrm{PM}_{2.5}$ cyclone at $4 \mathrm{~L} \mathrm{~min}^{-1}$. Known portions $(25 \mathrm{~g}$ ) of pork were individually cooked until well done and the emissions generated were sampled from the exhaust line.

The VOCs were measured by a proton-transfer-reaction mass spectrometer (PTR-MS, Ionicon Analytik). The drift tube was operated at $600 \mathrm{~V}$ at a constant pressure of 2.2$2.3 \mathrm{mbar}$. The flow rate was $0.5 \mathrm{~L} \mathrm{~min}^{-1}$. Further information about the PTR-MS operation can be found in Kaltsonoudis et al. (2016). Blank measurements were conducted prior to the introduction of meat cooking emissions to the chamber in each experiment. A series of gas monitors was used for the measurement of the mixing ratios of the nitrogen oxides $\left(\mathrm{NO}_{x}\right)$, ozone $\left(\mathrm{O}_{3}\right)$, carbon monoxide $(\mathrm{CO})$, and carbon dioxide $\left(\mathrm{CO}_{2}\right)$ (Teledyne models: T201, 400E, 300E, and T360, respectively).

Aging experiments were conducted in order to simulate the evolution of the freshly produced COA as it reacts with typical oxidants $\left(\mathrm{O}_{3}\right.$ and $\left.\mathrm{OH}\right)$ in the atmosphere. UV illumination was used $\left(J_{\mathrm{NO}_{2}}=0.59 \mathrm{~min}^{-1}\right)$ and the chemical evolution of the particulate and gas species was monitored. In some experiments, ozone was added and the ozonolysis of cooking emissions in the dark was investigated (Table 1). No $\mathrm{OH}$ precursor was used in any of the experiments.

\subsection{Ambient measurements}

Ambient aerosol was sampled at the ICE-HT institute ( $8 \mathrm{~km}$ NE from the center of Patras) during February 2012 (Kostenidou et al., 2013). This period included Fat Thursday (16 February) during which meat is charbroiled everywhere in Patras. The instrumentation used for the ambient mea- 
surements is described in Kostenidou et al. (2013). Briefly, an HR-ToF-AMS was deployed for the characterization of the non-refractory $\mathrm{PM}_{1}$ aerosol composition, a PTR-MS was used for the VOCs, an SMPS for the size distributions, a MAAP for the $\mathrm{BC}$, and a series of gas monitors were used for the $\mathrm{NO}_{x}, \mathrm{O}_{3}, \mathrm{CO}$, and $\mathrm{CO}_{2}$ concentrations. All instruments sampled from approximately $4 \mathrm{~m}$ above ground. A $\mathrm{PM}_{2.5} \mathrm{cy}-$ clone was used in front of the MAAP.

\subsection{Data analysis}

For the HR-AMS data analysis, SQUIRREL v1.56D and PIKA v1.15D with Igor Pro 6.34A (Wavemetrics) were used, applying the fragmentation table of Aiken et al. (2008). The $\mathrm{O}: \mathrm{C}$ and $\mathrm{H}: \mathrm{C}$ ratios were estimated using the improved method of Canagaratna et al. (2015). High-resolution PMF analysis (Paatero and Tapper, 1994; Lanz et al., 2007) was performed using the HR-AMS data from the chamber experiments and the ambient measurements. The PMF evaluation tool PET (Ulbrich et al., 2009) was used for both cases. The Multilinear Engine (ME-2) through Source Finder software (SoFi) (Canonaco et al., 2013) was also used for the analysis of the ambient measurements to investigate the robustness of the corresponding results of the PMF. In all cases we used the $m / z$ of 12-200 at high resolution as inputs.

The $\mathrm{OH}$ radical concentrations were estimated using isotopically labeled butanol (1-butanol-d9, Sigma). The change of the concentration of the PTR-MS $m / z 66$ was used to calculate the $\mathrm{OH}$ concentrations based on the second-order reaction of d9-butanol with the $\mathrm{OH}$ radicals. The corresponding reaction constant used is $3.4 \times 10^{12} \mathrm{~cm}^{3}$ molecule ${ }^{-1} \mathrm{~s}^{-1}$ (Barmet et al., 2012). The wall losses corrections for the particles inside the chamber were calculated according to Pathak et al. (2007) assuming a first-order loss rate for the mass concentration of the total OA. The loss rate constant was established during the characterization period of each experiment prior to the beginning of chemical aging. The wall rate constants obtained for the experiments were in the range of $0.14-0.28 \mathrm{~h}^{-1}$ and the corresponding linear fits had very high correlation coefficients. Losses of particles to the walls do remove part of the OA from the air in the chamber and make it "invisible" for our measurements. However, the observed chemical changes were relatively fast, taking place mostly within a couple of hours. The corresponding timescales for losses were $4-6 \mathrm{~h}$, so our conclusions are quite robust. This can be clearly seen, for example, in the dark ozonolysis experiment where fresh COA is decreasing following the $\mathrm{O}_{3}$ addition significantly faster than it is lost to the walls before aging begun. However, the fact that we could not observe the corresponding potential changes to the COA particles deposited on the walls introduces some uncertainty in the results. While one would expect similar changes in these deposited particles if mass transfer of oxidants and condensable material was rapid enough, we cannot confirm this. However, the effect of wall losses of particles on the observed
Table 2. Composition (\% mass) of the freshly emitted COA for the laboratory experiments.

\begin{tabular}{lrrrrrr}
\hline & \multicolumn{5}{c}{ Experiment } & Average \\
\cline { 2 - 6 } & 1 & 2 & 3 & 4 & 5 & \\
\hline Organics & 98.4 & 99.0 & 99.4 & 99.4 & 99.6 & $99.2 \pm 0.5$ \\
Sulfate & 0.1 & 0.5 & 0.1 & 0.1 & 0.1 & $0.1 \pm 0.2$ \\
Ammonium & 0.0 & 0.0 & 0.0 & 0.0 & 0.0 & $0.0 \pm 0.0$ \\
Chloride & 0.5 & 0.0 & 0.1 & 0.1 & 0.1 & $0.2 \pm 0.2$ \\
Nitrate & 0.2 & 0.1 & 0.2 & 0.3 & 0.2 & $0.2 \pm 0.1$ \\
BC & 0.8 & 0.4 & 0.2 & 0.2 & 0.1 & $0.3 \pm 0.3$ \\
\hline
\end{tabular}

SOA/POA ratio is expected to be from modest to small. This has also been addressed by the work of Hildebrandt et al. (2009), who discussed the extremes of the potential fate of particles deposited on smog chamber walls.

\section{Source characterization experiments}

\subsection{Size distribution and chemical composition of the fresh COA}

Table 2 summarizes the composition of the fresh cooking aerosol for the five chamber experiments. The emitted aerosol is dominated by organic compounds (above $99 \%$ ) in all experiments. $\mathrm{BC}$ was on average only $0.3 \%$ of the $\mathrm{PM}_{1}$. This is consistent with the OC and EC filter analysis of the $\mathrm{PM}_{2.5}$ aerosol that was sampled directly from the charbroiler. In these samples, the EC content for the fresh cooking emissions was less than $0.6 \%$ of the total carbon. McDonald et al. (2003) reported that EC emissions from charbroiling and grilling of chicken and beef were $0.3-2.7 \%$ of the total mass using charbroilers fueled by natural gas. Li et al. (2015) also reported low EC emissions due to cooking in China (1.8$10.7 \%$ for meat roasting, $7.5 \%$ for fish roasting, $6 \%$ for street snack broiling, $1.9 \%$ for cafeteria frying, and $10.7 \%$ for cafeteria broiling). In that study the WSOC-to-OC ratio was $0.05-0.15$, indicating that the freshly emitted aerosol was mostly hydrophobic.

Figure 1a depicts the average HR-AMS mass spectra for the fresh meat charbroiling emissions. The initial spectra in all five experiments were similar with each other having angles $\theta$ of $0-7^{\circ}$ ( $R^{2}$ ranging from 0.983 to 0.999 ). The comparison of the AMS spectra based on $\theta$ angles was favored for the analysis of the results in the present paper. Briefly, a $\theta$ of $0-5^{\circ}$ shows an excellent match between the two spectra (with an $R^{2}$ ranging approximately from 1 to 0.99 ), a $\theta$ of $6-10^{\circ}$ shows a good match (with an $R^{2}$ ranging approximately from 0.98 to 0.96 ), a $\theta$ of $11-15^{\circ}$ shows that the two spectra have many similarities but they are not quite the same (with an $R^{2}$ ranging approximately from 0.95 to 0.92 ), and finally a $\theta$ from 16 to $30^{\circ}$ indicates spectra from different sources though there is some limited similarity $\left(R^{2}\right.$ 

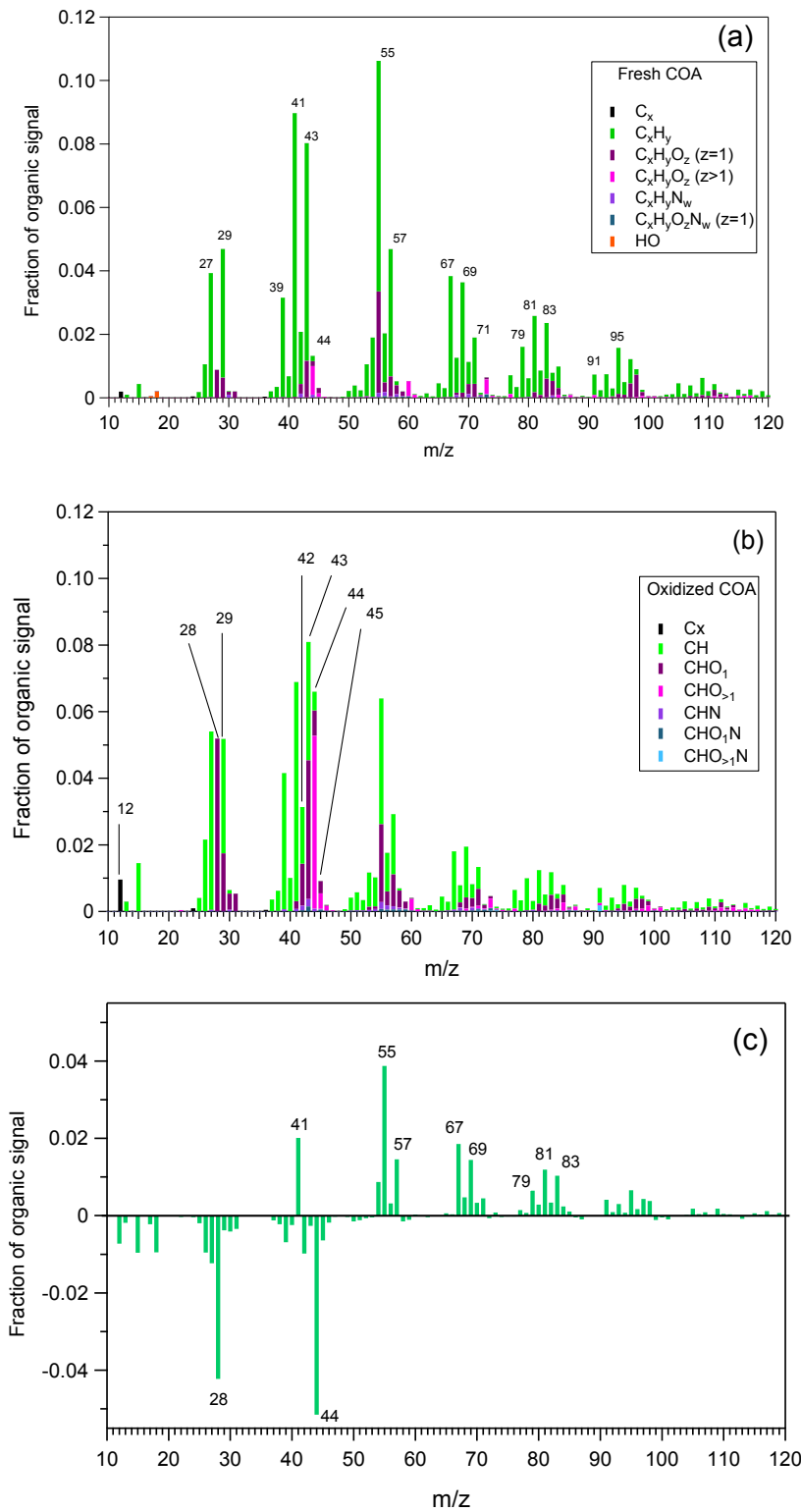

Figure 1. (a) Fresh COA mass spectrum, (b) aged COA mass spectrum for Experiment 2 ( $8 \mathrm{~h}$ of UV), and (c) the difference between the fresh and aged COA.

ranging approximately from 0.91 to 0.73 ). Values of $\theta$ higher than $30^{\circ}$ suggest clearly different spectra. The advantage of the $\theta$ angle use for mass spectra comparisons is that it can represent better small differences than the $R^{2}$ coefficient. For example, small differences of $1-5^{\circ}$ all correspond to $R^{2}=0.99$. The initial $\mathrm{O}: \mathrm{C}$ and $\mathrm{H}: \mathrm{C}$ ratios based on Canagaratna et al. (2015) and based on Aiken et al. (2008) in parenthesis were on average $0.10 \pm 0.01(0.08 \pm 0.01)$ and $1.94 \pm 0.03(1.80 \pm 0.03)$, respectively. The main peaks of the corresponding AMS spectra were at $m / z$ values 27, 29, 39, $41,43,55,57,67,69,71,79,81,83,91$, and 95 . The majority of these fragments correspond to homologous chains free
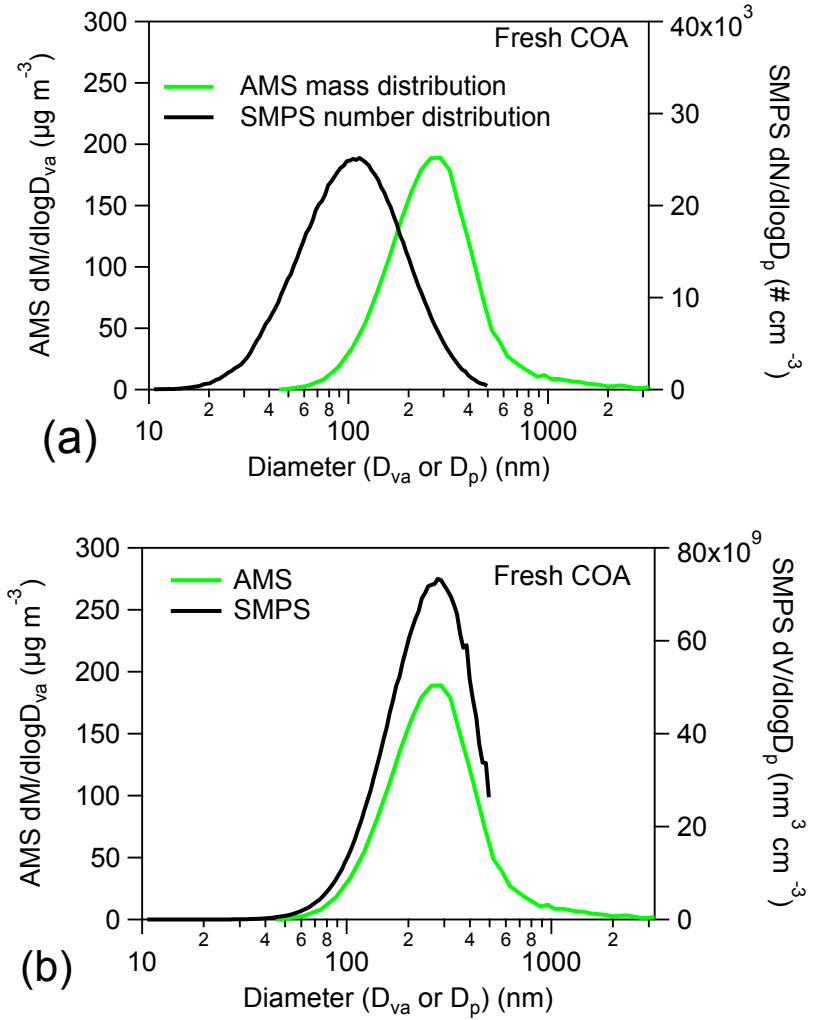

Figure 2. (a) SMPS number and AMS mass distributions versus $D_{\mathrm{p}}$ and $D_{\mathrm{va}}$ correspondingly for fresh COA and (b) SMPS volume and AMS mass distributions versus $D_{\mathrm{va}}$ and $D_{\mathrm{p}}$.

of oxygen. The gas-phase $\mathrm{CO}_{2}$ contribution to the $\mathrm{CO}_{2}^{+}$signal was corrected by sampling through a HEPA filter during the experiments. The $\mathrm{CO}_{2}$ levels were in the $395-435 \mathrm{ppm}$ range and did not change significantly during the course of each experiment.

The number-mode mobility diameter $\left(D_{\mathrm{p}}\right)$ of the fresh COA measured by the SMPS was $86 \pm 20 \mathrm{~nm}$, while the mass-mode vacuum aerodynamic diameter $\left(D_{\mathrm{va}}\right)$ measured by the AMS was $224 \pm 30 \mathrm{~nm}$. Figure $2 \mathrm{a}$ shows the fresh COA number and mass distributions versus $D_{\mathrm{p}}$ and $D_{\mathrm{va}}$ correspondingly for Experiment 1 . Figure $2 b$ shows the mass and volume distributions versus $D_{\mathrm{va}}$ and $D_{\mathrm{p}}$ correspondingly for the fresh COA in the same experiment. The AMS and the SMPS estimated aerosol mass concentrations were quite different during all chamber experiments. The SMPS mass concentrations were lower by approximately a factor of 5 for a density of $1 \mathrm{~g} \mathrm{~cm}^{-3}$ compared to the AMS total concentrations. Thus, an additional chamber experiment was conducted, where AMS and SMPS concentrations were compared to gravimetric measurements of the concentrations of COA samples collected on Teflon filters. For the same period the AMS mass concentration $(\mathrm{CE}=1)$ was $600 \mu \mathrm{g} \mathrm{m}^{-3}$, the SMPS (assuming density $1 \mathrm{~g} \mathrm{~cm}^{-3}$ ) was $100 \mu \mathrm{g} \mathrm{m}^{-3}$, and the filter-based concentration was $500 \mu \mathrm{g} \mathrm{m}^{-3}$. This intercom- 
parison shows that the SMPS mass concentrations assuming spherical particles are problematic probably because the fresh particles emitted from charbroiling are non-spherical. Katrib et al. (2005) reported that during the ozonolysis of stearic acid needle-shaped particles were identified by transmission electron microscopy. SEM pictures of fresh COA particles in our experiments also suggested that the particles were not spherical. However, particles evaporate in the SEM so the proof is not conclusive. Given that CE values less than unity would further increase the disagreement between the AMS and the SMPS estimates and that the density of COA should be less than $2 \mathrm{~g} \mathrm{~cm}^{-3}$, we estimate that the non-spherical shape of the particles introduces an error of the order of 2-4 in the volume concentration estimated by the SMPS measurements.

\subsection{COA emission rates}

Gravimetric analysis of the samples collected from above the charbroiler yielded an aerosol emission factor of $4 \mathrm{~g} \mathrm{~kg}^{-1}$ of meat cooked. Hildemann et al. (1991) studied the emissions from hamburger cooking of regular and lean meet either by frying or charbroiling and reported emissions between 1 and $40 \mathrm{~g} \mathrm{~kg}^{-1}$. McDonald et al. (2003) determined the emission ratios of meat cooking (hamburger, steak, and chicken) due to charbroiling or grilling and reported emission rates in the range 4-12 $\mathrm{g} \mathrm{kg}^{-1}$ (McDonald et al., 2003). These rates vary by more than 1 order of magnitude not only because different types of meat were cooked but also due to the different cooking procedures (charbroiling, grilling, frying, etc.), and cooking specifics (well-done, medium, slowly cooked, medium cooking time, etc.). Generally charbroiling emits more particles than frying and also the emissions increase with increasing fat content of the meat cooked. There is also additional variability related to where the meat is placed with respect to the very hot surfaces (e.g., charcoal). In the present study we tried to duplicate the cooking conditions and practices used in Greece.

\subsection{Emissions of volatile organic compounds}

Several VOCs were emitted during cooking though their concentrations compared to the PM were low. In most cases less than $1 \mathrm{ppb}$ of a specific VOC was emitted per $100 \mu \mathrm{g} \mathrm{m}^{-3}$ of PM. The aromatic species (benzene, toluene, xylenes) were emitted in similar amounts $\left(0.1 \mathrm{~g} \mathrm{~kg}^{-1}\right)$. Table 3 presents the emission factors for some of the measured VOCs based on a COA emission rate of $4 \mathrm{~g} \mathrm{~kg}^{-1}$ of meat. To the best of our knowledge there is little information about VOC emissions from cooking. For example, Schauer et al. (1999) reported the emission factors from meat charbroiling over a natural gas-fired grill. So our major objective was to add to this limited literature. Based on the emissions measured the SOA formation potential of cooking would be limited compared to the primary emissions. This is consistent with the limited
Table 3. Emission factors $\left(\mathrm{g} \mathrm{kg}^{-1}\right.$ of meat cooked) for several VOCs.

\begin{tabular}{lrr}
\hline VOC & $\begin{array}{r}\text { PTR-MS } \\
m / z\end{array}$ & $\begin{array}{r}\text { Emission rate } \\
\left(\mathrm{g} \mathrm{kg}^{-1}\right)\end{array}$ \\
\hline Acetonitrile & 42 & $0.01 \pm 0.00$ \\
Acetone & 59 & $0.03 \pm 0.01$ \\
Isoprene & 69 & $0.05 \pm 0.01$ \\
MVK and MACR & 71 & $0.03 \pm 0.01$ \\
MEK & 73 & $0.01 \pm 0.01$ \\
Benzene & 79 & $0.09 \pm 0.02$ \\
Toluene & 93 & $0.09 \pm 0.03$ \\
Xylenes & 107 & $0.10 \pm 0.04$ \\
Monoterpenes & 137 & $0.04 \pm 0.02$ \\
\hline
\end{tabular}

additional SOA that we have observed experimentally as discussed in the next section. There was no detectable decrease of the concentrations of the VOCs measured by the PTR-MS during the characterization periods.

\subsection{Chemical aging of COA}

Significant changes to the COA spectrum were observed during its oxidation. The initial and final $\mathrm{O}: \mathrm{C}$ and $\mathrm{H}: \mathrm{C}$ ratios for all the experiments are reported in Table 1. For Experiment 1 , in which the emissions were illuminated for $4 \mathrm{~h}$ the $\mathrm{O}: \mathrm{C}$ increased from 0.11 to 0.27 . For Experiment 2, where the UV lights were turned on for $8 \mathrm{~h}$, the $\mathrm{O}: \mathrm{C}$ reached 0.30 . For Experiment 3, in which dark ozonolysis took place, the $\mathrm{O}: \mathrm{C}$ ratio reached $0.212 \mathrm{~h}$ after the addition of $40 \mathrm{ppb}$ of ozone. For experiment 4 the $\mathrm{O}: \mathrm{C}$ ratio reached 0.27 after $7.5 \mathrm{~h}$ of exposure to UV. No change was seen for the $\mathrm{O}: \mathrm{C}$ and $\mathrm{H}: \mathrm{C}$ ratios for Experiment 5 in which the COA was left in the chamber without addition of oxidants or exposure to UV.

For the experiments in which UV illumination was used the $\mathrm{O}: \mathrm{C}$ ratio increased from 0.1 to 0.2 in less than $2 \mathrm{~h}$. For Experiment 3, in which $40 \mathrm{ppb}$ of $\mathrm{O}_{3}$ were added, the $\mathrm{O}: \mathrm{C}$ ratio increased from 0.12 to 0.18 in less than $1 \mathrm{~h}$. Figure 3 a shows the temporal evolution of the $\mathrm{O}: \mathrm{C}$ ratios during the five smog chamber experiments. In Experiment 3 (dark ozonolysis) an increase prior to the addition of ozone was seen due to small amounts of ozone (approximately $9 \mathrm{ppb}$ ) initially present in the chamber. Figure $3 \mathrm{~b}$ presents the corresponding $\mathrm{H}$ : $\mathrm{C}$ ratio evolution during the five experiments. A reduction in $\mathrm{H}: \mathrm{C}$ by $10 \%$ or so was observed in all experiments.

The $\theta$ angles between the fresh and aged COA AMS spectra are summarized in Table 1. Differences in the AMS spectra between the fresh and aged COA were present throughout the $m / z$ range. The fractional contribution of $m / z 44, f_{44}$, increased during the UV aging and the dark ozonolysis. Figure $1 \mathrm{~b}$ shows the aged COA HR spectrum for Experiment 2 (after $8 \mathrm{~h}$ of UV illumination). After aging with UV for $4 \mathrm{~h}$ 

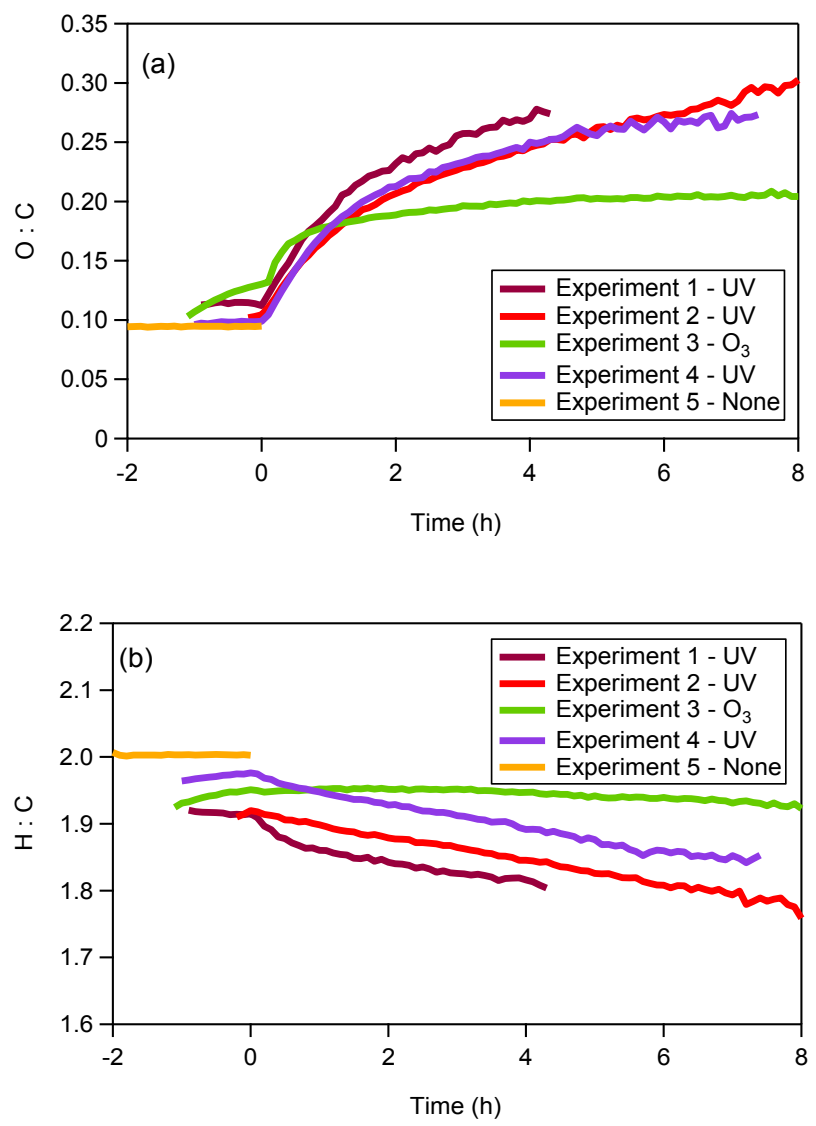

Figure 3. (a) $\mathrm{O}: \mathrm{C}$ ratios and (b) $\mathrm{H}: \mathrm{C}$ ratios for the $\mathrm{COA}$ smog chamber experiments. Time zero corresponds to the beginning of the aging process.

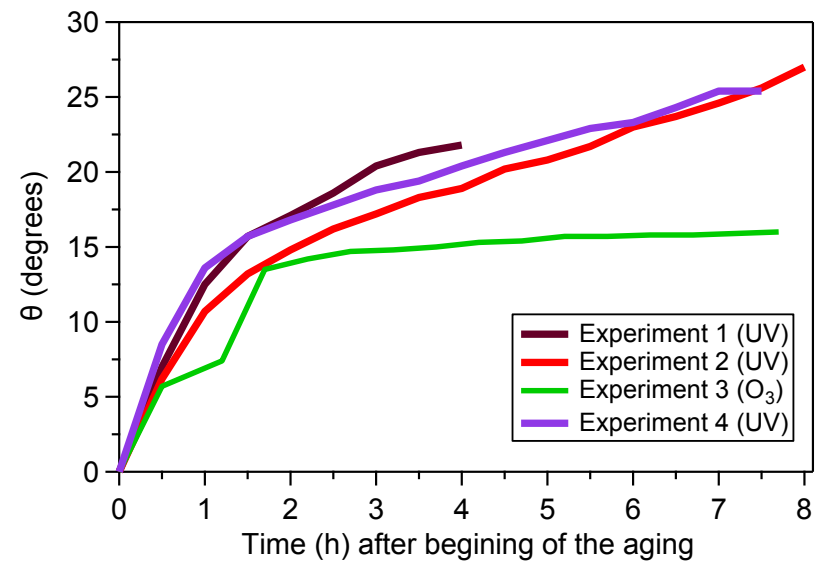

Figure 4. Evolution of the $\theta$ angle with the initial AMS mass spectrum during aging.

the $\theta$ angle was $22^{\circ}$ in experiment 1 . The addition of ozone resulted in a $15^{\circ}$ shift in $4 \mathrm{~h}$. The relatively fast change in the AMS spectra is noteworthy (Fig. 4). After $1 \mathrm{~h}$ of UV illumination a $\theta$ angle of $12^{\circ}$ was observed. For the dark ozonolysis experiment a $15^{\circ}$ change was observed $2 \mathrm{~h}$ after the ozone addition. These results indicate that the COA emitted from meat charbroiling can change rapidly after it is emitted either during the day (when it is sunny) or during the night when moderate levels of ozone are available.

Figure 5a shows the fraction of $m / z 44\left(f_{44}\right)$ and $m / z 43$ $\left(f_{43}\right)$ as they evolve over time during Experiment $2(8 \mathrm{~h}$ of UV). Most of the COA factors reported in the literature fall in the lower left part of the $\mathrm{Ng}$ triangle ( $\mathrm{Ng}$ et al., 2011). After the oxidation process the system position tends to move up as $f_{44}$ increases. A similar trend was observed for the $f_{55}$ to $f_{57}$ plot (Fig. 5b) where both fractions decrease due to chemical aging. A similar behavior was observed during ozonolysis (Fig. 5c and d).

The driving forces for these chemical aging processes were reactions with $\mathrm{O}_{3}$ and $\mathrm{OH}$ radicals. Significant $\mathrm{O}_{3}$ production was observed in the UV illumination experiments with at least $40 \mathrm{ppb}$ of $\mathrm{O}_{3}$ produced after a few hours of illumination. During the first hour, $15 \mathrm{ppb}$ was formed and after $2 \mathrm{~h}$ the ozone concentration reached $25 \mathrm{ppb}$. At the same time the $\mathrm{OH}$ radical concentration increased up to $5 \times 10^{6}$ molecules $\mathrm{cm}^{-3}$. Figure 6 a depicts the $\mathrm{O}_{3}$ and $\mathrm{OH}$ concentrations for Experiment 2 in which UV illumination was used. Similar results were obtained for the rest of the UV illumination experiments. Figure $6 \mathrm{~b}$ shows the $\mathrm{O}_{3}$ evolution during the dark ozonolysis experiment. After the initial addition of $40 \mathrm{ppb}$ of ozone, approximately $5 \mathrm{ppb}$ was consumed during the first $3 \mathrm{~h}$.

Net OA production due to chemical aging was limited. In the five experiments OA mass enhancements (after corrections for particle losses) were less than $10 \%$ of the mass prior to the perturbation. This small change in mass strongly suggests that a lot of the observed chemical changes were probably due to heterogeneous reactions. Such reactions can explain the significant changes in composition (e.g., O:C) and the small additional OA formation in these experiments. Kroll et al. (2015) observed similar changes in aerosol chemical composition during exposure to $\mathrm{OH}$ but at exposures that were more than 1 order of magnitude higher than those in our experiments. However, studies of the ozonolysis of COA components like oleic acid (e.g., Morris et al., 2002) suggest that the corresponding reactions have timescales of as little as minutes. These literature results suggest that ozonolysis was probably the dominating chemical aging pathway in our experiments.

While VOC concentrations remained stable when no UV light or oxidants were used, the concentrations of formaldehyde, acetaldehyde, formic acid, acetone, acetic acid, and methyl ethyl ketone all increased during the chemical aging. Approximately $15 \mathrm{ppb} / 100 \mathrm{\mu g} \mathrm{m}^{-3}$ of COA of acetaldehyde and $8 \mathrm{ppb} / 100 \mu \mathrm{g} \mathrm{m}^{-3}$ of COA of formaldehyde were produced during the exposure to $\mathrm{UV}$ and $\mathrm{O}_{3}$. The increase of the concentration of these relatively small compounds suggests that fragmentation of the mostly larger organic molecules emitted during meat charbroiling is taking place. It is not 
(a)

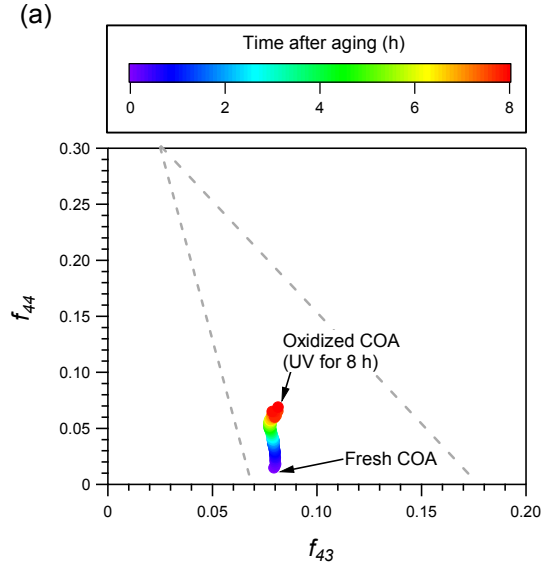

(c)
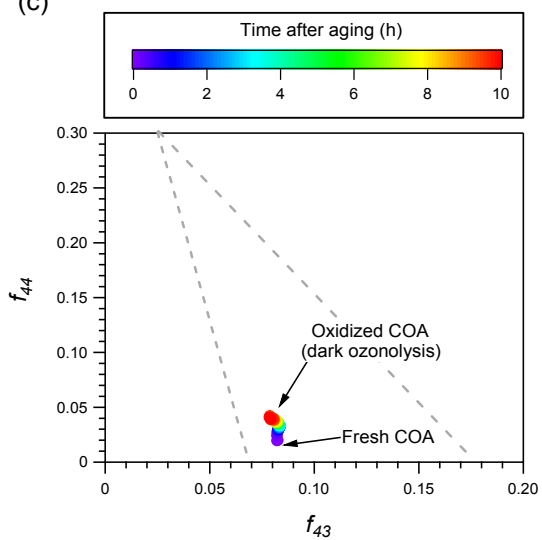

(b)

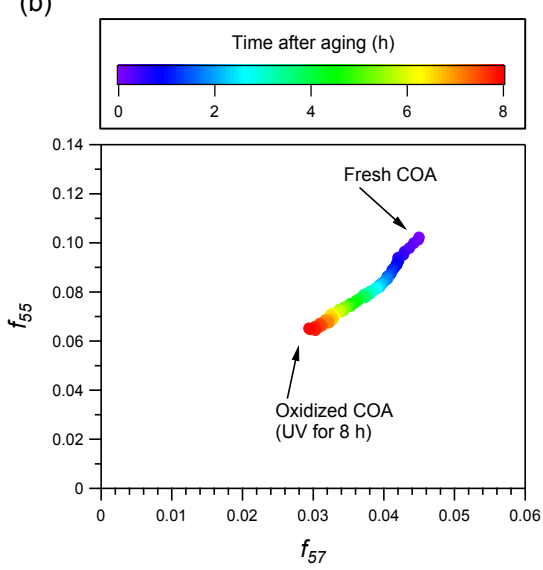

(d)

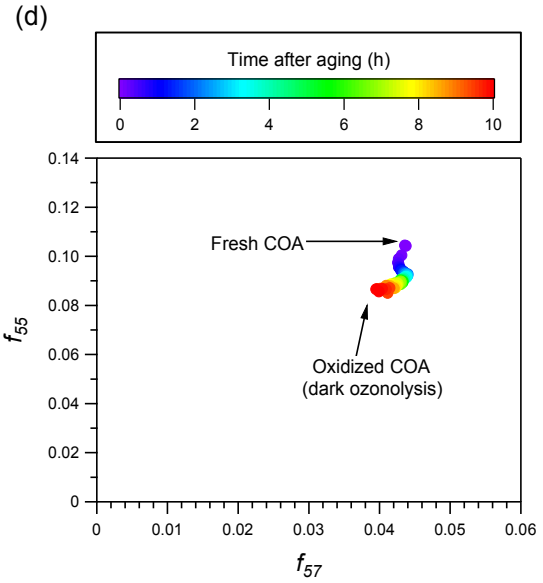

Figure 5. Scatter plot for the fractions of signal for Experiment 2 (UV for $8 \mathrm{~h}$ ) and Experiment 3. (a) $f_{44}$ to $f_{43}$ for Experiment 2 , (b) $f_{55}$ to $f_{57}$ for Experiment 2, (c) $f_{44}$ to $f_{43}$ for Experiment 3, and (d) $f_{55}$ to $f_{57}$ for Experiment 3 .

clear whether these molecules are products of the organics in the particulate phase (that is products of the heterogeneous reactions) or whether they were produced in the gas phase.

The water solubility of the COA also increased during its chemical aging. The WSOC / OC ratio for the fresh emissions was measured in each experiment and was always low with values in the $0.05-0.13$ range. The WSOC / OC ratio after chemical aging was measured in three experiments, two after UV illumination (experiments 1 and 2) and one after dark ozonolysis (Experiment 3). In all these three experiments the WSOC / OC ratio increased: to 0.7 for Experiment 1, 0.85 for Experiment 2, and 0.55 for Experiment 3. This shows that the WSOC / OC ratio of the aged COA is significantly higher than that of the fresh emissions and that the COA became a lot more hygroscopic as it aged.

HR-PMF analysis was performed for each chamber experiment separately. More information is provided in the Supplement (Sect. S1, Figs. S1-S18). For experiments 1-4 two factors were identified: a fresh and an aged factor. Figure 7 shows the mass spectra of the two factors for Experiment 1.
The mass spectra of the fresh COA factors had an O:C ratio of $0.09-0.11$ and they were very similar each other $\left(R^{2}>0.992, \theta<7^{\circ}\right)$. They were also close to the average fresh mass spectrum from all five experiments $\left(R^{2}>0.96\right.$, $\theta<10^{\circ}$ ). The aged factors had an $\mathrm{O}: \mathrm{C}$ ratio in the range of $0.20-0.26$ depending on the degree of oxidation. The AMS spectra of the aged factors after exposure to UV (experiments 1,2 , and 4$)$ were similar to each other $(\theta$ ranging from 2 to $\left.6^{\circ}\right)$. The corresponding angles between the dark ozonolysis experiment (Experiment 3 ) and the UV exposure ones were higher ranging from 8 to $14^{\circ}$ as the dark ozonolysis factor was less oxidized. Figure 8 illustrates the time series of the two factors for Experiment $3\left(\mathrm{O}_{3}\right)$ and Experiment 4 (UV).

\section{Ambient measurements}

Ambient aerosol was sampled outside the ICE-HT institute ( $8 \mathrm{~km} \mathrm{NE}$ from the city center of Patras) during February 2012 for a period of 2 days. This period included Fat Thurs- 

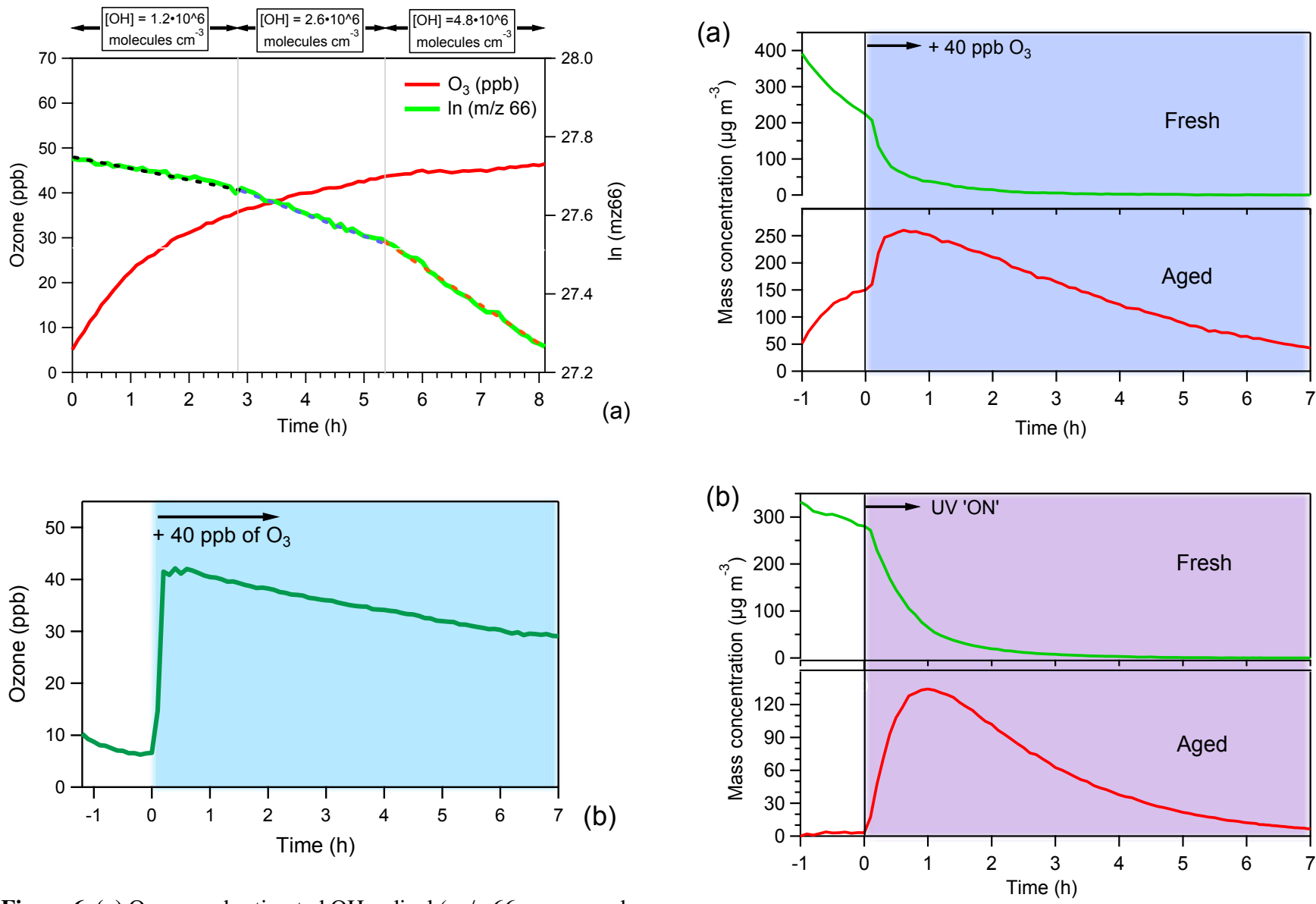

Figure 6. (a) Ozone and estimated $\mathrm{OH}$ radical $(\mathrm{m} / \mathrm{z} 66$ corresponds to d-butanol) concentrations in Experiment 2 (UV illumination) and (b) ozone concentration during Experiment 3 (dark ozonolysis).

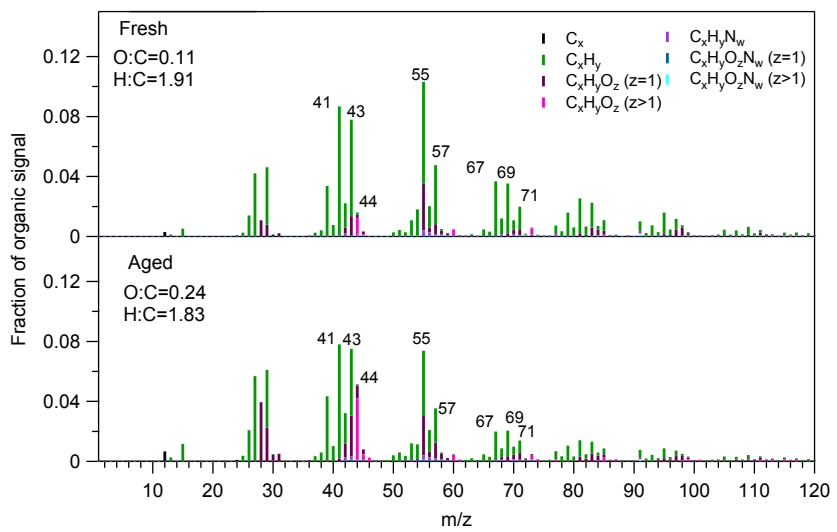

Figure 7. Mass spectra for the two resulting factors of the PMF analysis for Experiment 1.

day (16 February) during which meat is charbroiled everywhere in Patras. The ambient measurements have been corrected for the $\mathrm{CE}$, applying the algorithm of Kostenidou et al. (2007), comparing the AMS mass distributions to the SMPS volume distributions. The CE for these multi-

Figure 8. Time series of the resulting factors from the PMF analysis of the chamber experiments without corrections for losses to walls. (a) PMF factors for Experiment $3\left(\mathrm{O}_{3}\right.$ addition) and (b) PMF factors for Experiment 4 (UV illumination).

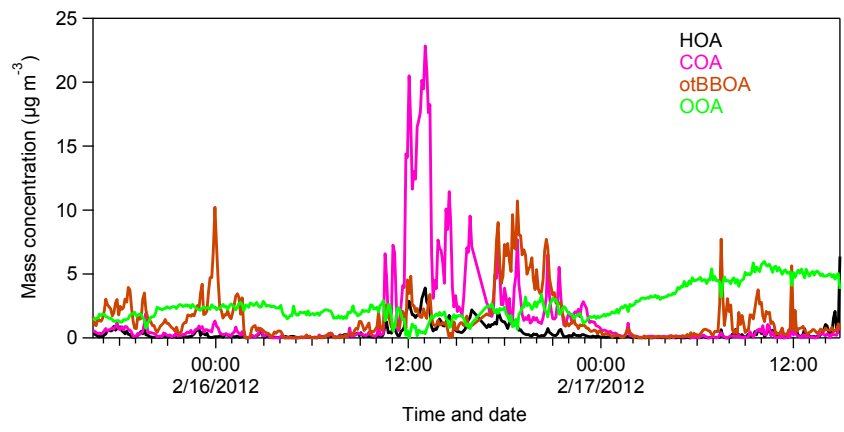

Figure 9. Time series of the four PMF factors found for the measurement period including Fat Thursday (16 February 2012).

component particles was $0.76 \pm 0.07$. Applying HR-PMF analysis (using PET) on the AMS spectra for these 2 days of measurements, four sources were identified. PMF solutions up to five factors were examined and evaluated, while the tested $f_{\text {peak }}$ range was between -2 and 2 . More informa- 


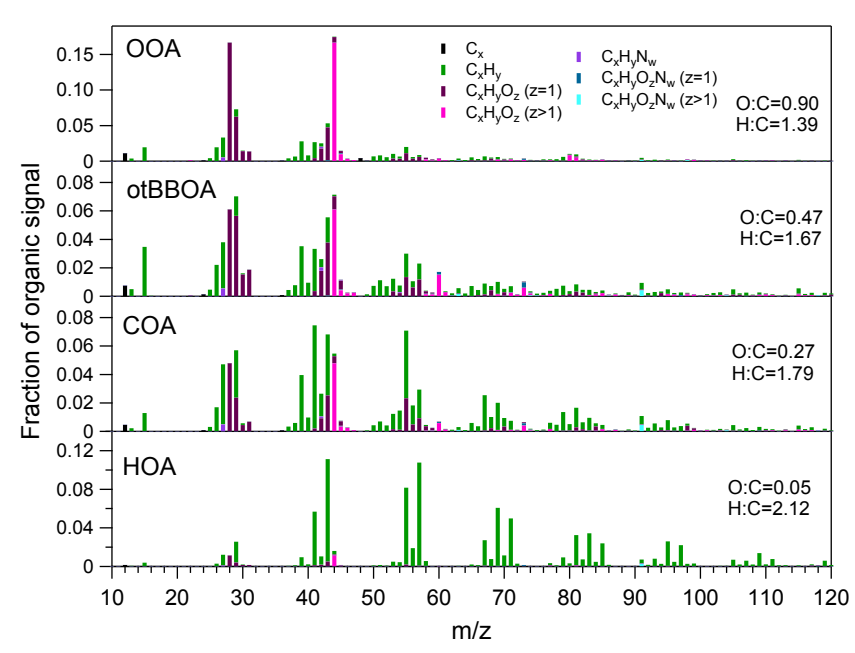

Figure 10. Mass spectra of the four PMF factors found for the measurement period including Fat Thursday (16 February 2012).

tion for the selection of the factors is provided in Sect. S2 and Figs. S19-S23. One factor was related to OOA, while the other three factors were attributed to primary emissions: transportation (HOA), burning of olive tree branches (otBB$\mathrm{OA}$ ), and meat cooking (COA). Given the small dataset, the stability of the solution was further investigated using ME2 analysis (SoFi) and applying a constrained solution for the HOA using the HOA mass spectrum of Kostenidou et al. (2013) with $a=0.1$ (Sect. S3, Figs. S24-S28). There was no significant change in the factors in the two solutions. More details are given in Sect. S3 and Figs. S23-S26. The cooking mass spectrum and time series did not change significantly with an $R^{2}>0.99$ between PMF and ME-2 solutions.

Figure 9 shows the mass concentrations of the four factors. During midday on Fat Thursday, the organic mass concentration was $23.2 \mu \mathrm{g} \mathrm{m}^{-3}$, representing $81 \%$ of the $\mathrm{PM}_{1}$. For the same period the cooking-related factor represented $85 \%$ of the organic aerosol $\left(17.5 \mu \mathrm{g} \mathrm{m}^{-3}\right)$, while for the day before and the day after the COA factor represented only $5 \%$ of the total OA. From various studies that were conducted in Greek cities, COA appears to be 15-20\% of the OA (Kostenidou et al., 2015; Florou et al., 2017). The mass spectrum of the COA along with the rest of the factors obtained by the PMF analysis is shown in Fig. 10. The $m / z$ values contributing significantly to the COA factor were $39,41,43,44,55,57,67$, 69,71 , etc., which are characteristic of cooking OA found in previous studies (Ge et al., 2012; Crippa et al., 2013a, b).

Figure 11 summarizes the angle $\theta$ between the mass spectra of the fresh and aged meat charbroiling OA and the PMF COA factors from ambient measurements from other studies. Depending on atmospheric conditions (oxidant levels) the COA AMS spectrum can be different. This can be seen by the comparison of fresh and aged COA in these experiments against the summer and winter COA factors in Greece. Other factors that appear to drive variability can include the PMF analysis itself (e.g., mixing with other sources), the type of food cooked, etc. The fresh laboratory COA spectrum has many similarities with the COA factors obtained in Athens and Patras during the winter ( $\theta$ angles of $13^{\circ}$ in both cases) especially considering that these are independent PMF results from different campaigns. In contrast, the aged COA spectrum is similar to the cooking-related factors (HOA-2) identified during the summer in both cities $\left(\theta\right.$ angles of $9^{\circ}$ for both). The spectrum of the cooking OA of Fat Thursday in Patras (a sunny period with moderate temperatures) was quite similar with the aged meat charbroiling aerosol. This demonstrates that COA ages relatively fast under ambient conditions when the necessary oxidants are available (i.e., sunny summer days) and as a result PMF analysis can distinguish only one factor (the aged COA). Even though this conversion is rapid the COA does not reach high-oxidation states comparable to those of OOA. In addition, our results suggest that before performing PMF analysis using default COA spectra as external factors, one should account for their potential chemical aging.

The aged COA spectrum from our chamber experiments is similar to the COA factor reported by Sun et al. (2011) for the city of New York during summer (Fig. 11). This is also true for the COA-related factor (CIOA) reported by Hayes et al. (2013) for the 2010 CalNex campaign in Pasadena, CA. However, the COA factors reported for Fresno (Ge et al., 2012) and Paris (Crippa et al., 2013b) were in better agreement with the fresh COA reported in this work.

\section{Conclusions}

Particulate emissions from meat charbroiling consist mainly of organics (>99\%) while BC is only $0.3 \%$. These fresh $\mathrm{OA}$ emissions react rapidly with ozone and $\mathrm{OH}$ radicals with significant changes in their AMS spectra. After $2 \mathrm{~h}$ of UV illumination (average $\mathrm{OH}$ concentration of $3 \times 10^{6} \mathrm{~cm}^{-3}$ ) the $\mathrm{O}: \mathrm{C}$ ratio doubles and the aged spectrum differs approximately $15^{\circ}$ from the fresh one. Fresh COA is hydrophobic (WSOC-to-OC ratio of $0.05-0.15$ ) while the aged COA is more hydrophilic (WSOC-to-OC ratio of 0.7-0.85).

The AMS spectrum of the fresh laboratory COA was similar $\left(\theta\right.$ less than $\left.10^{\circ}\right)$ to the ambient PMF COA winter factors in two major Greek cities, while it was quite different $\left(\theta 20-35^{\circ}\right)$ from the ambient summertime COA factors. The opposite behavior was observed for the aged COA, which was similar to the ambient summertime PMF COA factors $\left(\theta 10-12^{\circ}\right)$. These results suggest that the degree of chemical aging of the COA has to be taken into account for source identification in the PMF analysis of ambient AMS datasets.

The laboratory experiments were conducted at concentrations higher than atmospheric and this could be a potential limitation of the aging experiments. However, the concentrations in Experiment 1 when aging began were only a factor of 4 higher than the ambient COA levels shown in Fig. 9, so they 

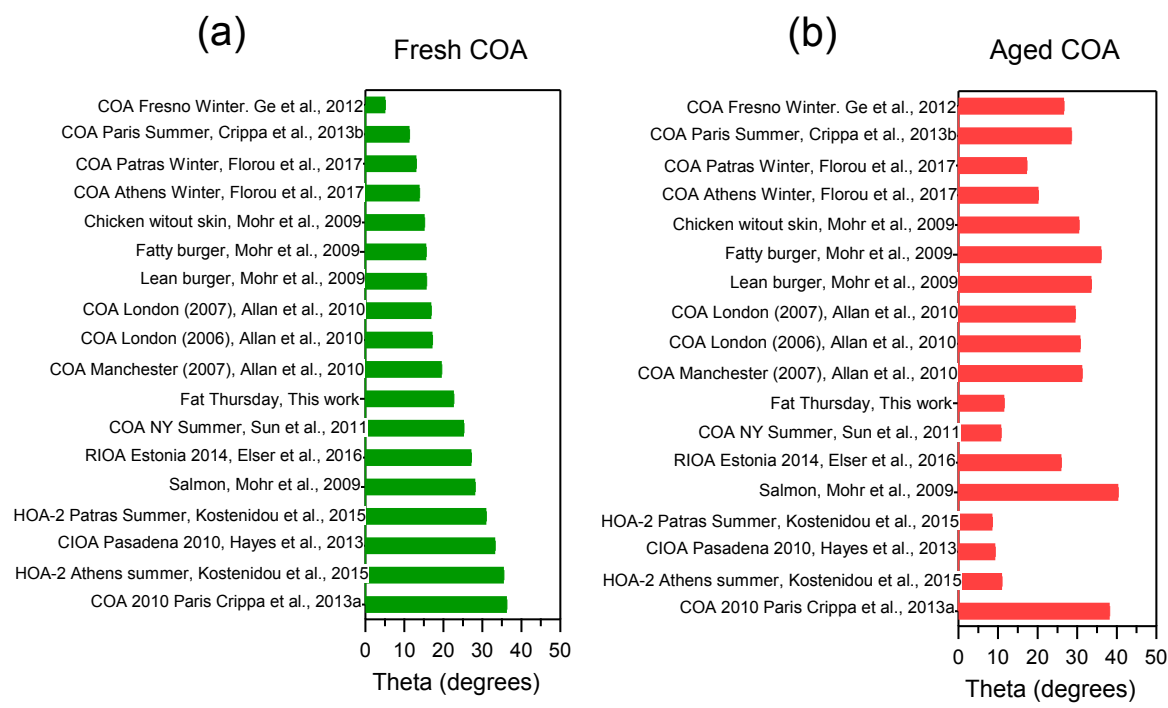

Figure 11. Angles $\theta$ between COA factors and the (a) fresh meat charbroiling emissions (average fresh spectrum) and (b) aged (average of the UV exposure experiments) meat charbroiling emissions.

are by no means unreasonable. The fact that we did not observe significant differences in behavior with initial concentration (the investigated variation was also a factor of 4) and the relatively good agreement of the aged laboratory COA AMS spectra with the ambient spectra suggests that the effect of the COA levels was probably not a serious limitation. The volatility of the cooking organic aerosol in these experiments as well as during the field campaign is discussed in a forthcoming publication.

Data availability. The related data are available on request from Spyros Pandis (spyros@chemeng.upatras.gr).

\section{The Supplement related to this article is available online at https://doi.org/10.5194/acp-17-7143-2017-supplement.}

Competing interests. The authors declare that they have no conflict of interest.

Acknowledgements. This research was supported by the European Research Council Project ATMOPACS (Atmospheric Organic Particulate Matter, Air Quality and Climate Change Studies) (grant agreement 267099) and the US Environmental Protection Agency (grant R835873). We thank M. Elser for making the AMS spectra from Estonia available. We also thank Patrick L. Hayes and Jose L. Jimenez for making the CIOA spectra available from CalNex campaign.

Edited by: Eleanor Browne

Reviewed by: two anonymous referees

\section{References}

Aiken, A. C., DeCarlo, P. F., Kroll, J. H., Worsnop, D. R., Huffman, J. A., Docherty, K., Ulbrich, I. M., Mohr, C., Kimmel, J. R., Sueper, D., Sun, Y., Zhang, Q., Trimborn, A. M., Northway, M. J., Ziemann, P. J., Canagaratna, M. R., Alfarra, M. R., Prevot, A. S. H., Dommen, J., Duplissy, J., Metzger, A., Baltensperger, U., and Jimenez, J. L.: O/C and OM/OC Ratios of Primary, Secondary, and Ambient Organic Aerosols with HighResolution Time-of-Flight Aerosol Mass Spectrometry, Environ. Sci. Technol., 42, 4478-4485, 2008.

Allan, J. D., Williams, P. I., Morgan, W. T., Martin, C. L., Flynn, M. J., Lee, J., Nemitz, E., Phillips, G. J., Gallagher, M. W., and Coe, H.: Contributions from transport, solid fuel burning and cooking to primary organic aerosols in two UK cities, Atmos. Chem. Phys., 10, 647-668, https://doi.org/10.5194/acp-10-6472010, 2010.

Barmet, P., Dommen, J., DeCarlo, P. F., Tritscher, T., Praplan, A. P., Platt, S. M., Prévôt, A. S. H., Donahue, N. M., and Baltensperger, $\mathrm{U}$.: $\mathrm{OH}$ clock determination by proton transfer reaction mass spectrometry at an environmental chamber, Atmos. Meas. Tech., 5, 647-656, https://doi.org/10.5194/amt-5-647-2012, 2012.

Canagaratna, M. R., Jimenez, J. L., Kroll, J. H., Chen, Q., Kessler, S. H., Massoli, P., Hildebrandt Ruiz, L., Fortner, E., Williams, L. R., Wilson, K. R., Surratt, J. D., Donahue, N. M., Jayne, J. T., and Worsnop, D. R.: Elemental ratio measurements of organic compounds using aerosol mass spectrometry: characterization, improved calibration, and implications, Atmos. Chem. Phys., 15, 253-272, https://doi.org/10.5194/acp-15-253-2015, 2015.

Canonaco, F., Crippa, M., Slowik, J. G., Baltensperger, U., and Prévôt, A. S. H.: SoFi, an IGOR-based interface for the efficient use of the generalized multilinear engine (ME2) for the source apportionment: ME-2 application to aerosol mass spectrometer data, Atmos. Meas. Tech., 6, 3649-3661, https://doi.org/10.5194/amt-6-3649-2013, 2013. 
Crippa, M., DeCarlo, P. F., Slowik, J. G., Mohr, C., Heringa, M. F., Chirico, R., Poulain, L., Freutel, F., Sciare, J., Cozic, J., Di Marco, C. F., Elsasser, M., Nicolas, J. B., Marchand, N., Abidi, E., Wiedensohler, A., Drewnick, F., Schneider, J., Borrmann, S., Nemitz, E., Zimmermann, R., Jaffrezo, J.-L., Prévôt, A. S. H., and Baltensperger, U.: Wintertime aerosol chemical composition and source apportionment of the organic fraction in the metropolitan area of Paris, Atmos. Chem. Phys., 13, 961981, https://doi.org/10.5194/acp-13-961-2013, 2013a.

Crippa, M., Haddad, I. E., Slowik, J. G., DeCarlo, P. F., Mohr, C., Heringa, M. F., Chirico, R., Marchand, N., Sciare, J., Baltensperger, U., and Prevot, A. S. H.: Identification of marine and continental aerosol sources in Paris using high resolution aerosol mass spectrometry, J. Geophysic. Res., 118, 1950-1963, https://doi.org/10.1002/jgrd.50151, 2013b.

Dall'Osto, M., Paglione, M., Decesari, S., Facchini, M. C., O'Dowd, C., Plass-Duellmer, C., and Harrison, R. M.: On the Origin of AMS "Cooking Organic Aerosol” at a Rural Site, Environ. Sci. Technol., 49, 13964-13972, 2015.

Elser, M., Bozzetti, C., El-Haddad, I., Maasikmets, M., Teinemaa, E., Richter, R., Wolf, R., Slowik, J. G., Baltensperger, U., and Prévôt, A. S. H.: Urban increments of gaseous and aerosol pollutants and their sources using mobile aerosol mass spectrometry measurements, Atmos. Chem. Phys., 16, 7117-7134, https://doi.org/10.5194/acp-16-7117-2016, 2016.

Florou, K., Papanastasiou, D. K., Pikridas, M., Kaltsonoudis, C., Louvaris, E., Gkatzelis, G. I., Patoulias, D., Mihalopoulos, N., and Pandis, S. N.: The contribution of wood burning and other pollution sources to wintertime organic aerosol levels in two Greek cities, Atmos. Chem. Phys., 17, 3145-3163, https://doi.org/10.5194/acp-17-3145-2017, 2017.

Ge, X., Setyan, A., Sun, Y., and Zhang, Q.: Primary and secondary organic aerosols in Fresno, California during wintertime: Results from high resolution aerosol mass spectrometry, J. Geophys. Res., 117, D19301, https://doi.org/10.1029/2012JD018026, 2012.

Hayes, P. L., Ortega, A. M., Cubison, M. J., Froyd, K. D., Zhao, Y., Cliff, S. S., Hu, W. W., Toohey, D. W., Flynn, J. H., Lefer, B. L., Grossberg, N., Alvarez, S., Rappenglück, B., Taylor, J. W., Allan, J. D., Holloway, J. S., Gilman, J. B., Kuster, W. C., de Gouw, J. A., Massoli, P., Zhang, X., Liu, J., Weber, R. J., Corrigan, A. L., Russell, L. M., Isaacman, G., Worton, D. R., Kreisberg, N. M., Goldstein, A. H., Thalman, R., Waxman, E. M., Volkamer, R., Lin, Y. H., Surratt, J. D., Kleindienst, T. E., Offenberg, J. H., Dusanter, S., Griffith, S., Stevens, P. S., Brioude, J., Angevine, W. M., and Jimenez, J. L.: Organic aerosol composition and sources in Pasadena, California, during the 2010 CalNex campaign, J. Geophys. Res., 118, 9233-9257, https://doi.org/10.1002/jgrd.50530, 2013.

He, L.-Y., Lin, Y., Huang, X.-F., Guo, S., Xue, L., Su, Q., Hu, M., Luan, S.-J., and Zhang, Y.-H.: Characterization of highresolution aerosol mass spectra of primary organic aerosol emissions from Chinese cooking and biomass burning, Atmos. Chem. Phys., 10, 11535-11543, https://doi.org/10.5194/acp-10-115352010, 2010.

Hearn, J. D., Lovett, A. J., and Smith, G. D.: Ozonolysis of oleic acid particles: evidence for a surface reaction and secondary reactions involving Criegee intermediates, Phys. Chem. Chem. Phys., 7, 501-511, 2005.
Hildebrandt, L., Donahue, N. M., and Pandis, S. N.: High formation of secondary organic aerosol from the photooxidation of toluene, Atmos. Chem. Phys., 9, 2973-2986, https://doi.org/10.5194/acp-9-2973-2009, 2009.

Hildemann, L. M., Markowski, G. R., Jones, M. C., and Cass, G. R.: Submicrometer aerosol mass distributions of emissions from boilers, fireplaces, automobiles, diesel trucks, and meatcooking operations, Aerosol Sci. Tech., 14, 138-152, 1991.

Kaltsonoudis, C., Kostenidou, E., Florou, K., Psichoudaki, M., and Pandis, S. N.: Temporal variability and sources of VOCs in urban areas of the eastern Mediterranean, Atmos. Chem. Phys., 16, 14825-14842, https://doi.org/10.5194/acp-16-148252016, 2016.

Kanakidou, M., Seinfeld, J. H., Pandis, S. N., Barnes, I., Dentener, F. J., Facchini, M. C., Van Dingenen, R., Ervens, B., Nenes, A., Nielsen, C. J., Swietlicki, E., Putaud, J. P., Balkanski, Y., Fuzzi, S., Horth, J., Moortgat, G. K., Winterhalter, R., Myhre, C. E. L., Tsigaridis, K., Vignati, E., Stephanou, E. G., and Wilson, J.: Organic aerosol and global climate modelling: a review, Atmos. Chem. Phys., 5, 1053-1123, https://doi.org/10.5194/acp-5-10532005, 2005.

Katrib, Y., Biskos, G., Buseck, P. R., Davidovits, P., Jayne, J. T., Mochida, M., Wise, M. E., Wornsop, D. R., and Martin, S. T.: Ozonolysis of mixed oleic acid/stearic acid particles: Reaction kinetics and chemical morphology, J. Phys. Chem. A, 109, 10910-10919, 2005.

Kostenidou, E., Pathak, R. K., and Pandis, S. N.: An Algorithm for the calculation of secondary organic aerosol density combining AMS and SMPS Data, Aerosol Sci. Tech., 47, 1002-1010, 2007.

Kostenidou, E., Lee, B. H., Engelhart, G. J., Pierce, J. R., and Pandis, S. N.: Mass spectra deconvolution of low, medium and high volatility biogenic secondary organic aerosol, Environ. Sci. Technol., 43, 4884-4889, 2009.

Kostenidou, E., Kaltsonoudis, C., Tsiflikiotou, M., Louvaris, E., Russell, L. M., and Pandis, S. N.: Burning of olive tree branches: a major organic aerosol source in the Mediterranean, Atmos. Chem. Phys., 13, 8797-8811, https://doi.org/10.5194/acp-138797-2013, 2013.

Kostenidou, E., Florou, K., Kaltsonoudis, C., Tsiflikiotou, M., Vratolis, S., Eleftheriadis, K., and Pandis, S. N.: Sources and chemical characterization of organic aerosol during the summer in the eastern Mediterranean, Atmos. Chem. Phys., 15, 11355-11371, https://doi.org/10.5194/acp-15-11355-2015, 2015.

Kroll, J. H., Lim, C. Y., Kessler, S. H., and Wilson, K. R.: Heterogeneous oxidation of atmospheric organic aerosol: Kinetics of changes to the amount and oxidation state of particle-phase organic carbon, J. Phys. Chem. A, 119, 10767-10783, 2015.

Lanz, V. A., Alfarra, M. R., Baltensperger, U., Buchmann, B., Hueglin, C., and Prévôt, A. S. H.: Source apportionment of submicron organic aerosols at an urban site by factor analytical modelling of aerosol mass spectra, Atmos. Chem. Phys., 7, 15031522, https://doi.org/10.5194/acp-7-1503-2007, 2007.

Lee, B. P., Li, Y. J., Yu, J., Louie, P., and Chan, C. K.: Characteristics of submicron particulate matter at the urban roadside in downtown Hong Kong - overview of 4 months of continuous high-resolution aerosol mass spectrometer (HRAMS) measurements, J. Geophys. Res. Atmos., 120, 7040-7058, https://doi.org/10.1002/2015JD023311, 2015. 
Li, Y. C., Shu, M., Ho, S. S. H., Wang, C., Cao, J. J., Wang, G. H., Wang, X. X., Wang, K., and Zhao, X. Q.: Characteristics of $\mathrm{PM}_{2.5}$ emitted from different cooking activities in China, Atmos. Res., 166, 83-91, 2015.

McDonald, J. D., Zielinska, B., Fujita, E. M., Sagebiel, J. C., Chow, J .C., and Watson, J. G.: Emissions from charbroiling and grilling of chicken and beef, J. Air Waste Ma., 53, 185-194, 2003.

Mohr, C., Huffman, A. J., Cubison, M. J., Aiken, A. C., Docherty, K. S., Kimmel, J. R., Ulbrich, I. M., Hannigan, M., and Jimenez, J. L.: Characterization of primary organic aerosol emissions from meat cooking, trash burning, and motor vehicles with highresolution aerosol mass spectrometry and comparison with ambient and chamber observations, Environ. Sci. Technol., 43, 2443 2449, 2009.

Mohr, C., DeCarlo, P. F., Heringa, M. F., Chirico, R., Slowik, J. G., Richter, R., Reche, C., Alastuey, A., Querol, X., Seco, R., Peñuelas, J., Jiménez, J. L., Crippa, M., Zimmermann, R., Baltensperger, U., and Prévôt, A. S. H.: Identification and quantification of organic aerosol from cooking and other sources in Barcelona using aerosol mass spectrometer data, Atmos. Chem. Phys., 12, 1649-1665, https://doi.org/10.5194/acp-121649-2012, 2012.

Morris, J. W., Davidovits, P., Jayne, J. T., Jimenez, J. L., Shi, Q., Kolb, C. E., Worsnop, D. R., Barney, W. S., and Cass G.: Kinetics of submicron oleic acid aerosols with ozone: A novel aerosol mass spectrometric technique, Geophys. Res. Lett., 29, 71-1-714, https://doi.org/10.1029/2002GL014692, 2002.

Ng, N. L., Canagaratna, M. R., Jimenez, J. L., Chhabra, P. S., Seinfeld, J. H., and Worsnop, D. R.: Changes in organic aerosol composition with aging inferred from aerosol mass spectra, Atmos. Chem. Phys., 11, 6465-6474, https://doi.org/10.5194/acp11-6465-2011, 2011.

Ots, R., Vieno, M., Allan, J. D., Reis, S., Nemitz, E., Young, D. E., Coe, H., Di Marco, C., Detournay, A., Mackenzie, I. A., Green, D. C., and Heal, M. R.: Model simulations of cooking organic aerosol (COA) over the UK using estimates of emissions based on measurements at two sites in London, Atmos. Chem. Phys., 16, 13773-13789, https://doi.org/10.5194/acp-16-137732016, 2016.

Pathak, R. K., Stanier, C. O., Donahue, N. M., and Pandis, S. N.: Ozonolysis of alpha-pinene at atmospherically relevant concentrations: Temperature dependence of aerosol mass fractions (yields), J. Geophys. Res., 112, D03201, https://doi.org/10.1029/2006jd007436, 2007.

Paatero, P. and Tapper, U.: Positive matrix factorization - a nonnegative factor model with optimal utilization of error-estimates of data values, Environmetrics, 5, 111-126, 1994.
Psichoudaki, M. and Pandis, S. N.: Atmospheric aerosol watersoluble organic carbon measurement: A theoretical analysis, Environ. Sci. Technol., 47, 9791-9798, 2013.

Rogge, W. F., Hildemann, L. M., Mazurek, M. A., and Cass, G. R.: Sources of fine organic aerosol. 1. Charbroilers and meat cooking operations, Environ. Sci. Technol., 25, 1112-1125, 1991.

Schauer, J. J., Kleeman, M. J., Cass, G., and Simoneit, B. T.: Measurement of emissions from air pollution sources. 1. $\mathrm{C}_{1}$ through $\mathrm{C}_{29}$ organic compounds from meat charbroiling, Environ. Sci. Technol., 33, 1566-1577, 1999.

Schauer, J. J., Kleeman, M. J., Cass, G. R., and Simoneit, B. T.: Measurement of emissions from air pollution sources. 4. $\mathrm{C}_{1}-\mathrm{C}_{27}$ organic compounds from cooking with Seed Oils, Environ. Sci. Technol., 36, 567-575, 2002.

Sun, Y.-L., Zhang, Q., Schwab, J. J., Demerjian, K. L., Chen, W.N., Bae, M.-S., Hung, H.-M., Hogrefe, O., Frank, B., Rattigan, O. V., and Lin, Y.-C.: Characterization of the sources and processes of organic and inorganic aerosols in New York city with a high-resolution time-of-flight aerosol mass apectrometer, Atmos. Chem. Phys., 11, 1581-1602, https://doi.org/10.5194/acp11-1581-2011, 2011.

Sun, Y. L., Zhang, Q., Schwab, J. J., Yang, T., Ng, N. L., and Demerjian, K. L.: Factor analysis of combined organic and inorganic aerosol mass spectra from high resolution aerosol mass spectrometer measurements, Atmos. Chem. Phys., 12, 8537-8551, https://doi.org/10.5194/acp-12-8537-2012, 2012.

Ulbrich, I. M., Canagaratna, M. R., Zhang, Q., Worsnop, D. R., and Jimenez, J. L.: Interpretation of organic components from Positive Matrix Factorization of aerosol mass spectrometric data, Atmos. Chem. Phys., 9, 2891-2918, https://doi.org/10.5194/acp-92891-2009, 2009.

Zhang, Q., Jimenez, J. L., Canagaratna, M. R., Allan, J. D., Coe, H., Ulbrich, I., Alfarra, M. R., Takami, A., Middlebrook, A. M., Sun, Y. L., Dzepina, K., Dunlea, E., Docherty, K., DeCarlo, P. F., Salcedo, D., Onasch, T., Jayne, J. T., Miyoshi, T., Shimono, A., Hatakeyama, S., Takegawa, N., Kondo, Y., Schneider, J., Drewnick, F., Borrmann, S., Weimer, S., Demerjian, K., Williams, P., Bower, K., Bahreini, R., Cottrell, L., Griffin, R. J., Rautiainen, J., Sun, J. Y., Zhang, Y. M., and Worsnop, D. R.: Ubiquity and dominance of oxygenated species in organic aerosols in anthropogenically-influenced northern hemisphere midlatitudes, Geophys. Res. Lett., 34, L13801, https://doi.org/10.1029/2007gl029979, 2007. 